for the medical inspection of school children had passed its third reading in the House of Commons. For the success of this measure Sir Philip Magnus, the educationist, representative in Parliament of the University of London, had been largely responsible.

The self-congratulations of the anthropologists on this measure were premature. While recognising its value, and well aware of the benefit which, as time has shown, it was to confer on the people, when the Act came into operation, they noted with regret that no provision was made for anthropometric measurement as a general operation, and no attempt was made to set up a racial standard or standards against which to measure the abnormal or under-developed. The results may be seen in some of the general conclusions put forward, especially in connexion with the effects of malnutrition, in early reports by medical officers who had not appreciated the finer points, patent to the anthropologist, in handling their material.

From this time forward, the project of a nationwide anthropometric survey, though not sinking entirely into oblivion, became less prominent. It merged into larger proposals which the Royal Anthropological Institute contemplated promoting, while the untimely death of John Gray in 1912 and the outbreak of War helped to relegate it still further to the background in which stood the many desirable things which were to await more propitious times.

In the meantime, also, active interest in anthropometric research had shifted to the regional surveys which were being carried out by individual workers, singly or in groups, and this up to the present has continued in the post-War period. Of these surveys, it is not possible to refer in detail and mention must be confined to one or two, such as that carried out by Prof. H. J. Fleure and his colleagues and pupils in Wales, of which an early report was presented at the Sheffield meeting of the British Association in 1910, the work of Prof. F. G. Parsons and his helpers in the Chilterns, which he has linked up with wider aspects of
British ethnology especially in connexion with skeletal material from London and, more recently, Miss R. M. Fleming's continuous periodical measurements of school children in Wales, and her study of hybrids.

The work carried out by Prof. Fleure, or under his inspiration, is especially important in connexion with the proposal which has been put forward by the Royal Anthropological Institute. Working with Aberystwyth as centre, Prof. Fleure and his pupils have demonstrated the relation of racial history to a number of sociological and economic problems. Of these investigations, not the least suggestive, from the point of view of practical politics, is the attempt to correlate, on scientific evidence above cavil, racial constitution and the incidence of disease.

Apart from its practical applications, to which due weight must be given when public assistance is sought, to the anthropologist the most pregnant feature in Prof. Fleure's work has been the demonstration of restricted areas in which has been found what appears to be the survival of a primitive-in some instances an extremely primitiveform among a population essentially modern in character. In this his work links up with the more subtle interpretation of the prehistoric skeletal remains which began, perhaps, in the opening years of the century with Prof. T. H. Bryce's survey of the prehistoric population of the shortcist graves of the Isle of Arran and the identification, soon afterwards, of the Beaker type, in the broad-headed skulls found in the neighbourhood of Aberdeen. As Prof. Fleure has again pointed out recently, the broad generalisations of racial history in Britain, however true at a certain level of thought, may mask rather than reveal facts of which a detailed view is needed. In linking up the prehistoric data with those relating to the modern population, the survey which the Royal Anthropological Institute contemplates will carry on methods of study which, as received from the hands of Prof. Fleure, have already had a profound effect in their application to racial problems in areas other than Wales.

\title{
Obituary
}

Prof. J. J. R. Mácleod, F.R.S.

$\mathrm{B}^{\mathrm{r}}$ the death after a long illness, on Saturday, March 16, of J. J. R. Macleod, regius professor of physiology in the University of Aberdeen, medical science has lost an outstanding worker.

John James Rickard Macleod, a son of the manse, was born at Cluny, near Dunkeld, on September 6, 1876. $\mathrm{H}_{\Theta}$ was educated at Aberdeen Grammar School and at the University of Aberdeen. $\mathrm{He}$ completed a distinguished undergraduate career by graduating M.B., Ch.B. with honours in 1898, being awarded at the same time the Anderson Travelling Scholarship. He worked for the next year in Germany, in the Institute of Physiology at Leipzig. In 1900 he was appointed demonstrator in physiology at the London Hospital Medical College and in 1902 was promoted to be lecturer in biochemistry. In 1901 he had been elected to the Mackinnon Scholarship of the Royal Society. He was appointed in 1903 to the chair of physiology at the Western Reserve University, 
Cleveland, Ohio, where he remained until 1918, when he was elected to the chair of physiology at Toronto. During his later years at Cleveland, he was engaged in various duties arising directly out of the War of 1914-18. He also acted as professor of physiology at MeGill University during part of the winter of 1916. After nine years at Toronto, he was appointed in 1928 to the regius professorship of physiology at Aberdeen, a post he was holding at his death.

Macleod's main interest and occupation throughout his academic life was, of course, the metabolism of carbohydrate. He published his first papers on experimental glycosuria in 1905, and between 1907 and 1917 a series of twelve papers under the general title of "Studies in Experimental Glycosuria" were published in the American Journal of Physiology as well as a series of eighteen papers between 1908 and 1921 dealing with other aspects of carbohydrate metabolism. Macleod had thus a full knowledge of practically all the phases of this field of metabolism and the intimate parts played in it by the main tissues and organs of the body. Thus equipped, he was both ready and willing in 1921 to put all the facilities of his laboratory and his unique knowledge of the subject at the disposal of the young investigator, F. G. Banting, who came to him with views on the isolation and preparation of the active principle of the internal secretion of the pancreas. The intensive research work which followed, in which two other collaborators deserve honourable mention, J. B. Collip and C. H. Best, culminated, as is well known, in the isolation of the active principle, insulin, from the islet tissue in such a pure form that it could be utilised as a medicament in practice. The original idea which started this particular piece of fundamental research in the Toronto laboratory was certainly Banting's, but, without the facilities and co-operation provided by Macleod and others, it is very doubtful if the investigation would have reached such early fruition. The marvel, indeed, is that such clean-cut and final results were obtained so speedily. The whole story is a testimonial to the value of team work ably directed to a single end.

Macleod's activities in the field of carbohydrate metabolism received a fresh impetus with the discovery of insulin, and most of his later experimental work was directed towards the mode of action of the active principle. His latest experiments were, in a way, a retrogression to the old ideas of Claude Bernard and his diabetic centre. Macleod had taken up the investigation of the nervous control of glycogenesis in the liver and had obtained some interesting and suggestive results.

Although Macleod's interests were centred on carbohydrate metabolism, he had from time to time carried out interesting investigations in other fields. $\mathrm{He}$ had published papers either alone, or in collaboration with others, on caisson sickness, the control of breathing, ventilation, the biochemistry of carbamates, phosphorus of muscle and on many other miscellaneous subjects. He published, in addition to several books dealing with insulin and carbohydrate metabolism, an original textbook, characteristic of the man's outlook, "Physiology and Biochemistry in Modern Medicine", which is now in its seventh edition.

In 1923 Macleod, jointly with Banting, was awarded the Nobel Prize in Physiology and Medicine, and in the same year was elected a fellow of the Royal Society. He was a fellow of the Royal Societies of Edinburgh and of Canada and a fellow of the Royal College of Physicians of London. In 1928 he was appointed Vanuxem Lecturer in the University of Princeton and in 1933 Herter Lecturer in Johns Hopkins University. He had been a member of the Medical Research Council (1929-33), past president of the Royal Canadian Institute (192526) and of the American Physiological Society (1922-23). He was a member of many learned societies, and held honorary degrees of several American universities as well as the LL.D. of his own Alma Mater.

As a man and a teacher Macleod was beloved by his friends and students alike. $\mathrm{He}$ was an excellent lecturer, lucid, happy and attractive. As a supervisor of research no one could have desired a more kindly and stimulating mentor. He was ever willing to listen and to help, no matter how slow the pupil, provided the worker was in earnest. As a man he was always happy, friendly and full of enthusiasm. He met every one with a cheery smile. He was an optimist who refused to be depressed by ill fortune ; and during the past four years he required all his optimism and cheoriness of spirit to stand up against his affliction. No one could have faced with greater patience and a braver spirit the handicaps placed upon him.

E. P. C.

\section{Prof. R. O. Herzog}

Prof. R. O. Herzog, who died at Zurich on February 4, made himself a name by discovering the microcrystalline structure of cellulose. $\mathrm{He}$ and Scherrer found it simultaneously and independently, when irradiating different kinds of cellulose fibres with $\mathrm{X}$-rays. This observation gave an enormous impetus to the investigation of fibres and organic substances of high molecular weight: twenty years ago, for example, no one would have dared to write down the structural formula of cellulose or to consider the rigidity of a macromolecule containing oxygen bridges, subjects of lively discussions at many scientific meetings nowadays. Herzog himself, then the head of the newly founded Kaiser Wilhelm. Institut für Faserstoffchemie at Berlin-Dahlem, was most active in promoting this development, and his vivid imagination played from the beginning with ideas which have materialised in recent years. Michael Polanyi, Karl Weissenberg, Hermann Mark, Max Bergmann and Erich Schmid did research in his laboratory at Dahlem, and it was remarkable how successfully Herzog was able to collaborate with younger men.

The behaviour of substances of high molecular weight had always interested Herzog. He was one of the first to determine the diffusion constants of proteins and enzymes, and to become acquainted 